\title{
Evaluation of serum transforming growth factor $\beta 1$ and $C$-reactive protein levels in migraine patients
}

\author{
Stężenia transformujqucego czynnika wzrostu $\beta 1$ i biatka C-reaktywnego u chorych \\ na migrenę
}

Işı| Güzel', Nebahat Taşdemir', Yusuf Çelik²

'Department of Neurology, Dicle University School of Medicine, Diyarbakir, Turkey

2Department of Biostatistics and Medical Informatics, Dicle University School of Medicine, Diyarbakir, Turkey

Neurologia i Neurochirurgia Polska 2013; 47, 4: 357-362

DOI: 10.5114/ninp.2013.36760

\begin{abstract}
Background and purpose: Migraine is a frequent form of headache. Although many mechanisms describing onset of migraine with and without visual aura have been suggested, the aetiology of migraine headaches is still not clear. Neurogenic inflammation may play a key role in the development of migraine headaches. We evaluated the discriminative power of serum levels of $\mathrm{C}$-reactive protein (CRP) and transforming growth factor beta 1 (TGF- $\beta 1$ ) in patients who presented to our clinic with migraine headaches with or without visual aura.
\end{abstract}

Material and methods: We designed a prospective case-control study of 51 patients with migraine (27 with migraine with aura and 24 with migraine without aura; all had headache) and compared them with 27 healthy subjects during the study period. Demographic and clinical characteristics recorded were age, sex, marital status, occupation, characteristics of headache, laboratory values, and serum CRP and TGF- $\beta 1$ levels. Statistical analyses used Student $t$-test, the $\chi^{2}$ test, and ANOVA followed by the post-hoc Bonferroni test for multiple comparisons. Receiver operator characteristic (ROC)curve analysis for CRP and TGF- $\beta 1$ was also conducted. Results: There was no difference between the groups in terms of demographic characteristics, marital status, and socioeconomic status. Statistically, white blood cell levels, serum glu-

\section{Streszczenie}

Wstęp i cel pracy: Migrena jest częstą postacią bólów głowy. Wskazywano wiele mechanizmów biorących udział w inicjowaniu napadu migreny $\mathrm{z}$ aurą wzrokową lub migreny bez aury, ale etiologia migrenowych bólów głowy nadal pozostaje niejasna. Kluczową rolę w rozwoju migreny może odgrywać zapalenie neurogenne. W pracy oceniono moc dyskryminacyjną stężeń białka C-reaktywnego (CRP) i transformującego czynnika wzrostu $\beta 1 \mathrm{w}$ surowicy pacjentów, którzy zgłaszali się do poradni z powodu bólów głowy w przebiegu migreny $\mathrm{z}$ aurą wzrokową lub bez aury.

Materiał i metody: W prospektywnym badaniu klinicznym z grupą kontrolną wzięło udział 51 chorych na migrenę (27 osób z migreną z aurą oraz 24 osoby z migreną bez aury; u wszystkich występował ból głowy) oraz 27 osób zdrowych. Rejestrowane zmienne demograficzne i kliniczne obejmowały: wiek, płeć, stan cywilny, zawód, charakterystykę bólu głowy oraz wyniki badań laboratoryjnych, w tym stężeń CRP i TGF- $\beta 1 \mathrm{w}$ surowicy. W analizach statystycznych wykorzystano test $t$ Studenta, test $\chi^{2}$ oraz analizę wariancji z testem post-hoc Bonferroniego ze względu na mnogie porównania. Przeprowadzono również analizę krzywych ROC dla CRP i TGF- $\beta 1$.

Wyniki: Nie stwierdzono różnic między grupami w odniesieniu do charakterystyki demograficznej, stanu cywilnego lub

Correspondence address: Işıl Güzel, Dicle University School of Medicine, Department of Neurology, Diyarbakir, Turkey, phone: + 904122488001 , fax:+904122488012,e-mail:dr.dulda@hotmail.com

Received: 9.01.2012; accepted: 4.12.2012 
cose levels, triglyceride levels, high-density lipoprotein levels, and serum CRP and TGF- $\beta 1$ were significantly higher in patients with migraine $(p<0.05)$. The ROC curve results in this study identified that CRP and TGF- $\beta 1$ may discriminate patients who have different types of migraine headache. Conclusions: This study suggests that serum CRP and TGF$\beta 1$ levels may be diagnostic factors to differentiate migraine patients with and without aura. These findings show that neurogenic inflammation may have a role in the aetiology of migraines.

Key words: migraine, aetiology, neurogenic inflammation, CRP, TGF- $\beta 1$.

\section{Introduction}

Migraine is a frequent form of headache, with symptoms that include severe headache attack, photophobia, nausea, vomiting, autonomic symptoms, and in some patients, visual aura involving neurological symptoms [1]. While the pathophysiology of migraines is still unclear, many pathophysiological mechanisms are related to the development of migraines, including vascular [2], neurogenic [3], hypoxic [4], and trigeminovascular [5] involvement.

Cutter et al. [2] provided evidence to support the vascular theory by showing a decrease in blood flow in the occipital lobe during the migraine aura. Lance [3] revealed an important step in the genesis of migraine by demonstrating that diffuse projections from the locus coeruleus to the cerebral cortex could initiate cortical oligaemia, possibly spreading depression caused by serotonin [3].

Another theory of migraine pathogenesis is neurogenic inflammation. It was first described by Dalessio [6], who showed that migraine occurred as a result of vasodilatation associated with a sterile local inflammatory reaction. Alterations of some interleukins have been reported in migraineurs [7]. C-reactive protein (CRP) [8] and transforming growth factor $\beta 1$ (TGF- $\beta 1$ ) [9] are considered to have a role in inflammation. The level of CRP, an acute-phase protein in blood, rises in response to inflammation [10]. TGF- $\beta 1$ is a polypeptide member of the transforming growth factor beta super-family of cytokines. It is a secreted protein that is involved in many cellular functions, including the control of cell growth, cell proliferation, cell differentiation, apoptosis, and inflammation [11]. Previous studies evaluated the association of CRP and TGF- $\beta 1$ with clinical characteristics in migraine patients $[12,13]$ and reported that $\mathrm{CRP}$ and TGF- $\beta 1$ might have a role in migraine pathogenesis. społeczno-ekonomicznego. U chorych na migrenę obserwowano większą liczbę leukocytów we krwi obwodowej oraz większe stężenia glukozy, triglicerydów, lipoprotein o dużej gęstości, CRP i TGF- $\beta 1(p<0,05)$. W analizie krzywych ROC stwierdzono, że CRP i TGF- $\beta 1$ mogą służyć do rozróżniania pacjentów z różnymi rodzajami bólów głowy.

Wnioski: Wyniki badania wskazują, że stężenia CRP i TGF- $\beta 1$ mogą służyć do odróżniania pacjentów z migreną $\mathrm{z}$ aurą od chorych na migrenę bez aury. Wyniki te sugerują, że zapalenie neurogenne może odgrywać rolę w etiologii migreny.

Słowa kluczowe: migrena, etiologia, zapalenie neurogenne, białko C-reaktywne, transformujący czynnik wzrostu $\beta 1$.

In the current study, we aimed to investigate the role of TGF- $\beta 1$ in migraine, to determine the diagnostic role of this interleukin in migraine, and to compare it with CRP, which has been shown previously to play a role in neurogenic inflammation.

\section{Material and methods}

This prospective case-control study was performed from June 2009 to June 2010 in the Dicle University School of Medicine, Department of Neurology, a tertiary referral hospital in the south-eastern region of Turkey. Most of the patients were referred to our hospital from area health centres. The health services were mostly free of charge and supported by the government. The study was approved by the Ethics Committee of the Dicle University School of Medicine (no. 77-02.07.10), and written informed consent was received from all of the patients.

The diagnosis of migraine with and without visual aura was made using the 2004 International Headache Society classification (ICHD-II) [14]. Table 1 shows the features of patients' headaches. The features analysed were unilateral pain, pulsating quality, moderate or severe pain intensity, aggravation by physical activity, nausea and/ or vomiting, photophobia, and phonophobia. A total of 78 persons were included in the study. Of these, 51 were the study group with headache (27 patients experienced aura [migraine with aura] and 24 did not [migraine without aura]). The control group included 27 subjects who were free of migraine and headache. Excluded from this study were pregnant or lactating women, patients with daily use of drugs (except hormonal contraceptives), patients with active infection, and patients with cardiovascular diseases, hypertension, diabetes mellitus, or hypercholesterolaemia. Based on medical history, physical examination, and routine laboratory tests, the control- 
Table 1. Headache characteristics in the studied patients

\begin{tabular}{|lcc|}
\hline Variables & $\begin{array}{c}\text { Patients with } \\
\text { migraine with aura* } \\
(\mathbf{n}=\mathbf{2 7})\end{array}$ & $\begin{array}{c}\text { Patients with } \\
\text { migraine without aura* } \\
\text { (n = 24) }\end{array}$ \\
\hline Unilaterality & $20(74.0 \%)$ & $16(66.6 \%)$ \\
\hline Pulsating quality & $26(96.2 \%)$ & $20(83.3 \%)$ \\
\hline Moderate or severe pain intensity & $24(88.8 \%)$ & $20(83.3 \%)$ \\
\hline Aggravation by physical activity & $18(66.6 \%)$ & $15(62.5 \%)$ \\
\hline Nausea and/or vomiting & $23(85.1 \%)$ & $20(83.3 \%)$ \\
\hline Photophobia & $20(74.0 \%)$ & $21(87.5 \%)$ \\
\hline Phonophobia & $24(88.8 \%)$ & $22(91.6 \%)$ \\
\hline *Data presented as $n(\%)$ & &
\end{tabular}

group participants were healthy subjects without headache, history of headaches, or first-degree relatives with headaches.

Demographic and clinical characteristics recorded were age, sex, marital status, job, characteristics of headache, laboratory values, and serum CRP and TGF- $\beta 1$ levels. Fasting blood samples were obtained from the antecubital vein during a headache-free period of 12 hours. Serum was collected within one hour and kept frozen at $-80^{\circ} \mathrm{C}$ until analysis. CRP levels were determined by the CRP kit (Beckman Coulter, immage S/N 2528, Fullerton, California, USA). TGF- $\beta 1$ levels were determined by the nephelometric method with an enzyme-linked immunosorbent assay (Invitrogen, Camarillo, CA, USA).

\section{Statistical analysis}

Mean values and standard deviations (SD) were calculated for continuous variables. The normality of the variables was analysed by the Kolmogorov-Smirnov test. The $\chi^{2}$ test and independent sample $t$-test were used to evaluate associations between categorical and continuous variables, respectively. The mean values of the three groups were analysed using one-way ANOVA followed by the post-hoc Bonferroni test for multiple comparisons. Variables were included in the backward and stepwise procedures. The sample size was determined according to the results of the central limit theorem [17], which indicated that at least 30 individuals were required in each subgroup. Receiver operator characteristic (ROC)-curve analysis was used to establish the cut-off values for CRP and TGF- $\beta 1$. Two-sided $p$-values were considered statistically significant at $p<0.05$. Statistical analyses were carried out using SPSS 15.0 for Windows (SPSS, Inc., Chicago, IL, USA).

\section{Results}

The demographic characteristics of the study group are shown in Table 2 . There were no statistically significant differences among the groups in terms of age, job, marital status, or socioeconomic status $(p>0.05)$. The control group included $11(40.7 \%)$ male and 16 (59.3\%) female participants. Of these, 17 (62.9\%) were married; most of them were homemakers and volunteer workers. None of the patients had clinical evidence of active infection. There were no statistically significant differences between the patient groups in terms of age, duration of illness, or family history.

Table 3 compares the laboratory values between the groups. Statistically, there were no significant differences between the groups in terms of alanine aminotransferase or aspartate aminotransferase levels $(p>0.05)$. Whole blood count levels, glucose levels, and serum lipid levels, including triglyceride and high-density lipoprotein levels, were significantly higher in the migraine groups compared with controls $(p<0.05)$.

Serum CRP and TGF- $\beta 1$ levels were determined in the three groups and the results are shown in Table 4. According to the Bonferroni method, there were statistically significant differences among the three groups in terms of CRP and TGF- $\beta 1$ levels (Table 4).

Areas under the receiver operating characteristic curves (AUC-ROC) for CRP and TGF- $\beta 1$ are shown in Figure 1. 
Table 2. Demographic and clinical characteristics of the migraine patients

\begin{tabular}{|c|c|c|c|c|}
\hline & $\begin{array}{c}\text { Patients with migraine } \\
\text { with aura } \\
(n=27)\end{array}$ & $\begin{array}{l}\text { Patients with migraine } \\
\text { without aura } \\
(n=24)\end{array}$ & $\begin{array}{l}\text { Statistics } \\
\text { p-value }\end{array}$ & $\begin{array}{l}\text { and } \\
\text { es }\end{array}$ \\
\hline Age [years], mean $\pm \mathrm{SD}$ & $36.62 \pm 2.65$ & $35.16 \pm 2.53$ & $t=0.396$ & $p=0.694$ \\
\hline \multicolumn{3}{|l|}{ Gender } & \multirow{3}{*}{$\chi^{2}=0.074$} & \multirow{3}{*}{$p=0.786$} \\
\hline Male & $7(25.9 \%)$ & $8(33.4)$ & & \\
\hline Female & $20(74.1 \%)$ & $16(66.6)$ & & \\
\hline \multicolumn{3}{|l|}{ Job } & \multirow{3}{*}{$\chi^{2}=2.107$} & \multirow{3}{*}{$p=0.716$} \\
\hline Housewife & $16(59.3 \%)$ & $14(58.3)$ & & \\
\hline Other $^{\mathrm{a}}$ & $11(40.7 \%)$ & $10(41.7)$ & & \\
\hline \multicolumn{3}{|l|}{ Marital status } & \multirow{3}{*}{$\chi^{2}=0.336$} & \multirow{3}{*}{$p=0.786$} \\
\hline Married & $20(74.1 \%)$ & $16(66.6)$ & & \\
\hline Single & $7(25.9 \%)$ & $8(33.4)$ & & \\
\hline \multicolumn{3}{|l|}{ Socioeconomic status } & \multirow{4}{*}{$t=2.346$} & \multirow{4}{*}{$p=0.546$} \\
\hline$<500 \mathrm{TL}$ & $17(62.9 \%)$ & $16(66.6 \%)$ & & \\
\hline $500-1000 \mathrm{TL}$ & $6(22.2 \%)$ & $5(20.8 \%)$ & & \\
\hline$>1000 \mathrm{TL}$ & $4(14.9 \%)$ & $3(12.6 \%)$ & & \\
\hline
\end{tabular}

"Data presented as $n$ (\%) if not stated otherwise.

- teacher, official, student, free worker

$S D$ - standard deviation, $T L$ - Turkish lira

Table 3. Comparison of laboratory values among three studied groups (ANOVA followed by Bonferroni test)*

\begin{tabular}{|c|c|c|c|c|c|c|}
\hline Variables & $\begin{array}{l}\text { Patients with } \\
\text { migraine with aura } \\
\text { (n=27) } \\
\text { Group A }\end{array}$ & $\begin{array}{l}\text { Patients with migraine } \\
\text { without aura } \\
(n=24) \\
\text { Group B }\end{array}$ & $\begin{array}{l}\text { Control } \\
\text { group } \\
(n=27) \\
\text { Group C }\end{array}$ & $F$ statistic & $P$-value & $\begin{array}{c}\text { P-value for } \\
\text { the Bonferroni } \\
\text { test }^{g}\end{array}$ \\
\hline $\begin{array}{l}\text { Glucose } \\
(\mathrm{mg} / \mathrm{dL})\end{array}$ & $97.11 \pm 14.11$ & $95.70 \pm 9.87$ & $126.66 \pm 6169$ & 5.690 & 0.005 & $\begin{array}{l}\text { A vs. } \mathrm{B}, p=0.128 \\
\text { A vs. C, } p<0.001 \\
\mathrm{~B} \text { vs. } \mathrm{C}, p<0.001\end{array}$ \\
\hline $\begin{array}{l}\operatorname{ALT}(\mathrm{U} / \mathrm{L}) \\
\operatorname{AST}(\mathrm{U} / \mathrm{L}) \\
\text { Cholesterol } \\
(\mathrm{mg} / \mathrm{dL})\end{array}$ & $\begin{aligned} 23.70 & \pm 23.30 \\
21.96 & \pm 8.41 \\
182.18 & \pm 35.69\end{aligned}$ & $\begin{aligned} 21.41 & \pm 11.47 \\
20.12 & \pm 6.68 \\
178.87 & \pm 27.17\end{aligned}$ & $\begin{aligned} 28.92 & \pm 16.50 \\
22.96 & \pm 6.03 \\
172.44 & \pm 47.70\end{aligned}$ & $\begin{array}{l}1.187 \\
1.204 \\
0.453\end{array}$ & $\begin{array}{l}0.311 \\
0.364 \\
0.637\end{array}$ & $\begin{array}{l}\text { Not followed } \\
\text { Not followed } \\
\text { Not followed }\end{array}$ \\
\hline $\begin{array}{l}\text { Triglyceride } \\
(\mathrm{mg} / \mathrm{dL})\end{array}$ & $118.00 \pm 54.05$ & $122.91 \pm 96.62$ & $214.00 \pm 137.48$ & 7.443 & 0.001 & $\begin{array}{l}\text { A vs. } \mathrm{B}, p=0.215 \\
\text { A vs. C, } p<0.001 \\
\text { B vs. C, } p<0.001\end{array}$ \\
\hline $\begin{array}{l}\text { HDL } \\
(\mathrm{mg} / \mathrm{dL})\end{array}$ & $52.62 \pm 10.97$ & $52.45 \pm 16.88$ & $48.16 \pm 13.68$ & 9.162 & $<0.001$ & $\begin{array}{l}\text { A vs. } \mathrm{B}, p>0.816 \\
\text { A vs. C, } p=0.019 \\
\text { B vs. C, } p=0.014\end{array}$ \\
\hline $\begin{array}{l}\mathrm{LDL} \\
(\mathrm{mg} / \mathrm{dL})\end{array}$ & $100.00 \pm 28.86$ & $97.37 \pm 24.23$ & $94.92 \pm 36.19$ & 0.188 & 0.829 & Not followed \\
\hline
\end{tabular}

*Data presented as means \pm standard deviations

${ }^{g} P$-value was calculated by using post-hoc test for non-parametric methods that is corrected ANOVA using Bonferroni test (for $A$ vs. $B, A$ vs. C and B vs. $C p<0.016$ accepted to be statistically different according to Bonferroni test)

$A L T$ - alanine aminotransferase, $A S T$ - aspartate aminotransferase, $H D L$ - high-density lipoprotein, $L D L$ - low-density lipoprotein

\section{Discussion}

We designed a case-control study to determine the pathophysiology of migraine. The study included $27 \mathrm{pa}-$ tients with migraine with aura, 24 patients with migraine without aura, and 27 controls without migraine. The levels of CRP and TGF- $\beta 1$ were higher in the migraine patient group compared with the control group. These 
Table 4. Results of comparison of the means of three groups in terms of CRP and TGF- $\beta 1$ levels by using ANOVA followed by Bonferroni test*

\begin{tabular}{|c|c|c|c|c|c|c|}
\hline Variables & $\begin{array}{l}\text { Patients with } \\
\text { migraine with aura } \\
\text { (n=27) } \\
\text { Group A }\end{array}$ & $\begin{array}{l}\text { Patients with } \\
\text { migraine without aura } \\
\text { ( } n=24 \text { ) } \\
\text { Group B }\end{array}$ & $\begin{array}{l}\text { Control group } \\
(n=27) \\
\text { Group C }\end{array}$ & $F$ statistic & $P$-value & $\begin{array}{l}\text { P-value for the } \\
\text { Bonferroni test }\end{array}$ \\
\hline $\begin{array}{l}\text { C-RP } \\
(\mathrm{mg} / \mathrm{dL})\end{array}$ & $1.562 \pm 0.72$ & $1.120 \pm 0.28$ & $0.350 \pm 0.16$ & 4.010 & 0.015 & $\begin{array}{l}\text { A vs. } \mathrm{B}, p=0.281 \\
\text { A vs. C, } p<0.001 \\
\text { B vs. C, } p<0.001\end{array}$ \\
\hline $\begin{array}{l}\text { TGF- } \beta 1 \\
(\mathrm{ng} / \mathrm{mL})\end{array}$ & $0.457 \pm 0.11$ & $0.441 \pm 0.09$ & $0.370 \pm 0.10$ & 3.936 & 0.026 & $\begin{array}{l}\text { A vs. } B, p=0.673 \\
\text { A vs. } C, p=0.021 \\
B \text { vs. } C, p=0.010\end{array}$ \\
\hline
\end{tabular}

"Data presented as means \pm standard deviations

xp-value was calculated by using post-hoc test for non-parametric methods that is corrected $A N O V A$ using Bonferroni test (for $A$ vs. $B, A$ vs. $C$ and $B$ vs. $C p<0.016$ accepted to be statistically different according to Bonferroni test)

$C R P-C$-reactive protein, TGF- $\beta 1$ - transforming growth factor $\beta 1$

results support the role of inflammation in the pathophysiology of migraine. Serum lipid levels were found to be higher in the migraine patient group, and this finding may support the vascular theory of migraine. Our findings also support previous studies that found an association between migraine and increased plasma lipid levels $[15,16]$. Larger studies with more patients should be conducted to examine the involvement of neurogenic inflammation in migraine. ROC analysis determined that TGF- $\beta 1$ may have strong discriminative power in differentiating patients with aura and without aura in migraine.

The relationship between neurogenic inflammation and migraine was first determined by Dalessio [6], who showed that migraine occurs as a result of vasodilatation associated with a sterile local inflammatory reaction. Moskowitz et al. $[13,14]$ also reported that sterile neurogenic inflammation may have a role in migraine pain $[13,14]$. In the neurogenic inflammation theory, release of vasoactive mediators from trigeminal perivascular fibres results in vasodilatation, plasma protein extravasations, and a decrease in proinflammatory mediators [14]. To examine the association between migraine and neurogenic inflammation, various interleukins have been evaluated $[8,18,19]$. Calcitonin gene-related peptide (CGRP) is an endogenous inflammatory mediator found to have a role in migraine and neurogenic inflammation, which causes dilation of cranial blood vessels, and this also supports the vascular theory of migraine [20]. Likewise, the role of CRP $[21,22]$ and TGF- $\beta 1$ [10] levels has been studied to determine the association between migraine and neurogenic inflammation.

CRP levels rise in response to inflammation [23]. TGF- $\beta 1$ is a polypeptide member of the transforming growth factor beta super-family of cytokines. It is a secreted protein that performs many cellular functions,

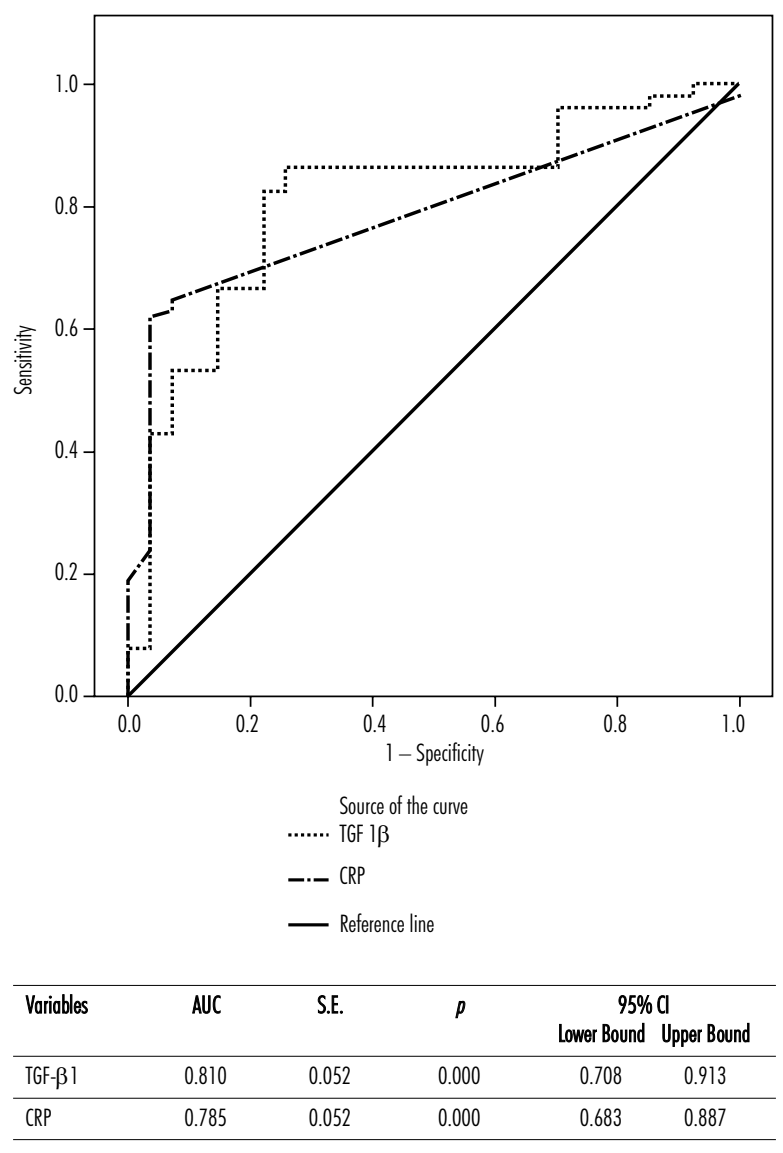

Fig. 1. Receiver operating characteristic (ROC) areas under the curves (AUC) of C-reactive protein (CRP) and transforming growth factor $\beta 1$ (TGF- $\beta$ l)

including contributing to the control of cell growth, cell proliferation, cell differentiation, apoptosis, and inflammation [11].

Vanmolkot et al. [21] reported that serum CRP levels were higher in migraine patients and highest in the 
migraine without aura group, and this finding supports the role of neurogenic inflammation in migraine. Similarly, we found higher serum CRP levels in our migraine patient group; however, in contrast to the study by Vanmolkot et al., the migraine with aura group had the highest CRP levels. Our data also suggest that neurogenic inflammation may have a role in migraine pathophysiology.

Welch et al. [22] evaluated the levels of serum CRP in migraine patients who presented with complex clinical features. According to that study, serum CRP levels were higher in patients with atypical, severe, or complex clinical features. That study also showed the association between neurogenic inflammation and migraine.

The only study evaluating TGF- $\beta 1$ levels in migraine is that of Ishizaki et al. [23]. In that study, Ishizaki et al. reported that TGF- $\beta 1$ levels were higher in the migraine group and highest in the migraine with aura group. The elevated levels of TGF- $\beta 1$ may be related to aura symptoms in migraine patients. We also found higher TGF- $\beta 1$ levels in migraine patients, and they were highest in the migraine with aura group. To our knowledge, this is the first study to evaluate both serum $\mathrm{CRP}$ and TGF- $\beta 1$ levels in migraine patients.

\section{Conclusions}

Our results indicate that neurogenic inflammation may have a role in the pathophysiology of migraine.

\section{Acknowledgement}

We thank www.textcheck.com for English revision.

\section{Disclosure}

Authors report no conflict of interest.

\section{References}

1. Arulmozhi D.K., Veeranjaneyulu A., Bodhankar S. Migraine: current concepts and emerging therapies. Vasc Pharmacol 2005; 43: 176-187.

2. Cutter F.M., Sorenson A.G., Weisskoff R.M., et al. Perfusionweighted imaging defects during spontaneous migraine aura Ann Neurol 1998; 43: 25-31.

3. Lance J.W. Current concepts of migraine pathogenesis. Neurology 1993; 43 (Suppl 3): 11-15.

4. Appenzeller O. Pathogenesis of migraine. Med Clin North Am 1991; 75: 763-789.
5. Moskowitz M.A. Neurogenic inflammation in the pathophysiology and treatment of migraine. Neurology 1993; 43 (6 Suppl 3): S16-S20.

6. Dalessio D.J. Vascular permeability and vasoactive substances: their relationship to migraine. Adv Neurol 1974; 4: 395-401.

7. Knoflach M., Kiechl S., Kind M., et al. Cardiovascular risk factors and atherosclerosis in young males: ARMY study (atherosclerosis risk-factors in male youngsters). Circulation 2003; 108 : 1064-1069.

8. Munno I., Marinaro M., Bassi A., et al. Immunological aspects in migraine: increase of IL-10 plasma levels during attack. Headache 2001; 41: 764-767.

9. Yasunari K., Maeda K., Nakamura M. Oxidative stress in leukocytes is a possible link between blood pressure, blood glucose, and C-reactive protein. Hypertension 2002; 39: 777-780.

10. Clark D.A., Coker R. Transforming growth factor-beta (TGFbeta). Int J Biochem Cell Biol 1998; 30: 293-298.

11. Marek A., Brodzicki J., Liberek A., et al. TGFbeta (transforming growth factor-beta) in chronic inflammatory conditions a new diagnostic and prognostic marker? Med Sci Monit 2002; 8: RA145-RA151.

12. D'Andrea G., Cananzi A.R., Perini F., et al. Platelet models and their possible usefulness in the study of migraine pathogenesis. Cephalalgia 1995; 15: 265-271.

13. Kemper R.H., Meijler W.J., Korf J., et al. Migraine and function of the immune system: a meta-analysis of clinical literature published between 1966 and 1999. Cephalalgia 2001; 21: 549-557.

14. Headache Classification Committee of the International Headache Society. The International Classification of Headache Disorders. $2^{\text {nd }}$ ed. Cephalalgia 2004; 1: 24.

15. Monastero R., Pipia C., Cefalu A.B., et al. Association between plasma lipid levels and migraine in subjects aged $>$ or $=50$ years: preliminary data from the Zabut Aging Project. Neurol Sci 2008; 29 (Suppl 1): S179-S181.

16. Camarda C., Monastero R., Pipia C., et al. Interictal executive dysfunction in migraineurs without aura: relationship with duration and intensity of attacks. Cephalalgia 2007; 27: 1094-1100.

17. Celik Y. Biostatistics, principles of research. Dicle University Press, Diyarbakir 2007.

18. Moskowitz M.A. The neurobiology of vascular head pain. Ann Neurol 1984; 16: 157-168.

19. Markowitz S., Saito K., Moskowitz M.A. Neurogenically mediated leakage of plasma protein occurs from blood vessels in dura mater but not brain. J Neurosci 1987; 7: 4129-4136.

20. Durham P.L. Calcitonin gene-related peptide (CGRP) and migraine. Headache 2006; 46 (Suppl 1): S3-S8.

21. Vanmolkot F.H., de Hoon J.N. Increased C-reactive protein in young adult patients with migraine. Cephalalgia 2007; 27: 843-846.

22. Welch K.M., Brandes A.W., Salerno L., et al. C-reactive protein may be increased in migraine patients who present with complex clinical features. Headache 2006; 46: 197-199.

23. Ishizaki K., Takeshima T., Fukuhara Y., et al. Increased plasma transforming growth factor-beta1 in migraine. Headache 2005; 45: 1224-1228.

24. Thompson D., Pepys M.B., Wood S.P. The physiological structure of human C-reactive protein and its complex with phosphocholine. Structure 1999; 15: 169-177. 